\title{
Study on Reading Service of University Library in Network Environment
}

\author{
Song Deng ${ }^{1}$ and Jun Wang ${ }^{2}$ \\ ${ }^{1}$ Library, Beijing Jiaotong University, Beijing 100044, P.R. CHINA \\ sdeng@bjtu.edu.cn \\ ${ }^{2}$ School of Science, Beijing Jiaotong University, Beijing 100044, P.R. CHINA \\ wangjun@bjtu.edu.cn
}

\begin{abstract}
We study the reading service of university library in the age of network, information and digital. Along with the rapid development of information technology, network technology and digital technology, the work of library should be innovated and changed, in order to adapt to the rapid development of the information society. In this work, we shall discuss the innovation methods of university library reading service in various aspects.
\end{abstract}

Keywords: Network environment, information technology, digital technology, university library, reading service, literature information

\section{Introduction}

Along with the rapid development and the increasing popularity of information technology, network technology and digital technology, the needs of readers and users for literature information show the diversified, the integrated and the efficient trends. Conform to the development of new ideas and new concepts, as the staffs of university library, we should play full attention to library's advantages in knowledge resources, and the development of innovative services for the readers is the bounden duty of the library $[3,4,6,7,10,11]$.
In the nowadays, the existing reading service of university library can not meet the needs of readers and users, we should break the traditional reading service modes, update the reading service concepts, breaking the traditional service models, changing the passive serviceoriented services to the initiative serviceoriented services, changing from providing a single paper literature to providing a comprehensive information resource $[1,2,5,8,9,12,13]$. In order to take full advantage of the university resources, we should continuously expand the scope of service, improve service quality, to adapt to the needs for the rapid development of today's information society. Network system, digital system and information technology have made the university library become the important base of school information and society information $[1,2,5]$.

\section{Features of Traditional Reading Service of Library in University}

\subsection{A limited read, borrow and re- turn with low-level passive service}

The traditional reading service is mainly confined to the literature (books and periodicals) of the library, also including the borrowing and the copy of the literature, and the simply consulting. Meanwhile, in the management of the literature of university library, it used to focus on collecting and maintaining functions of the li- 
brary, ignoring using functionality. In this case, the service of library is considered to be not sufficient nowadays, since it is usually lack of enthusiasm and initiative. Facing the growing special needs of the readers, it is difficult to carry out deep and diverse information service and advisory service.

\subsection{Books and periodicals are placed and managed individually}

Currently, most university libraries set each carrier of books, periodicals and journals in accordance with the characteristics of these literatures, for example, they can be arranged in alphabet or subject. And these literatures are often arranged in different reading rooms in the university library. This separation layout of literature books and periodicals splits the professional linkages between books and periodicals in the physical space. This also brings the inconvenient to the readers in the process of using the literature, this is also not conducive to carry out deep-level access to the university library services. In addition, the considerable numbers of libraries set the books and the corresponding CDs in the different carriers, which are usually placed in the reading room and the electronic reading room respectively. This also affects the reader's using to some extent, especially for the CDs (which accompany with the corresponding books), there is a low utilization rate. This results in a waste of resources.

\subsection{The service quality of library needed to be improved}

Since the university library is a subsidiary part of the university, there are subject to certain restrictions in the introduction of talent persons and the flows of talent persons. And the university library has a passive acceptance of the school's staffing, and becomes a preferred unit for the shunt placement of the university personnel and the families of introduced persons. These result in the uneven levels of academic librarians, and it is widespread that the professional qualities of the university librarians are low.

\section{Innovation and Change of Reading Service of Library in Network En- vironment}

\subsection{Make a new environment of liter- ature information in the reading room}

The means of networking and dissemination of digital information break the boundary space of the library, and the progress of network and digitization has prompted many university libraries to achieve the management of books, periodicals, web, stockpile, borrowing and reading into the "unified" management. Reading room is no longer only to display the printed books, but also should be to create a new document information environment for the readers. Divided by the discipline, books, literatures and relevant materials are professional neatly arranged in the large professional reading room, and there also the computer terminals set up in the reading room. The reader can not only choose to read professional printed literature, he can also access the network using the library-related databases and the electronic literature. New environment of

literature information allows the reader to meet and make the full use of literature information.

In May 2010, Beijing Jiaotong University Library established the "Architecture and Art" comprehensive reading room. In the reading room of "Architecture and Art", there are architecture and art books, current periodicals in foreign languages, foreign periodicals. And when ordering an annual journal of art and architecture, 
we would fully consider the suggestions of faculty in School of Architecture and Art. The establishment of this comprehensive reading room is well to meet the needs of teachers and students in School of Architecture and Art, this work received wide acclaim from teachers and students. In addition, changing the traditional reading rules and regulations of library is a service innovation for an effective way to reading service. From 2010, Beijing Jiaotong University Library implemented the short-term lending service for the books and periodicals, this kinds of service not only make readers can focus on study and research by full use of literature, but also extend the time of using the literature, and improve the utilization of library literature.

\subsection{Deepen reading service mode and establish special digital infor- mation resources}

In order to carry out the information value-added services, it is necessary to exploit the literature of library. Along with the network technology widely used in the library, it is possible to use the Internet to conduct multi-mode devices for reading services, and further expand and deepen the services of university library. This is also the reading service trends for the university libraries. Under the network environment, users are increasingly demanding the information of the literature. While meeting the needs of readers who come to borrow in library, the library should provide readers with online services. The library not only provides the library resources, but also does the collection, processing, development and utilization of the network literature resources. The library should make the implementation of a full range of open service, and gradually implement the proactive service to replace the passive services. In the network environment, it should be the demand-driven of the read- ers, the service of library should become the multi-carrier, multi-disciplinary and multi-form direction. The library can use of modern communication technology, computer, Internet and other information resources to form a full range of information services. Based on the reader feedback and the aspects of corresponding research and analysis, the library should constantly adjust to improve the service for the readers, through the filtering of information resources, reorganization, consolidation, concentration, etc., to achieve the value-added of knowledge, to form the latest information, to provide readers with high-used valued, personalized and targeted services.

Conducting the definite tracking service. For the school academic leaders, we periodically transmit the forefront research information in the corresponding research field, to provide them with regular service, convenient and flexible way of borrowing mode, to meet their specific needs. For the key disciplinary research projects, we would focus on providing key services to the academic teachers and an active participation in research projects, we should understand their requirements in depth. The librarians should carry out the regular search, novelty search, research, tracking and other services, in order to provide timely novel, targeted information resources for the researchers.

Establish the special digital information resources is an important way to the construction of information resources for the reading room, it is also a powerful tool for the collection of information resources and the development of social information resources. For the key disciplines of the university, the staffs of reading room should broaden the scope of services, based on the characteristic resources and orderly collecting the supplement of network-related resources, the librarians can filter out the valuable in- 
formation, and construct the special databases by themselves. This can achieve the characteristic database in the network environment for the interlibrary exchanging and the resource sharing. One library can combine with other distinctive library resources, and together to build university library with full featured security resources system. Beijing Jiaotong University Library "Digital Railroad Museum" and "Rail Transport Features Database" are the part of these special resources. In the process of building a database of these characteristic systems, the reading room staffs make a certain contributions to these systems.

\section{Strengthen Reading Guide for Reading Room Staffs}

In order to make the management of books, periodicals, web, stockpile, borrowing and reading into the "unified" management, reading room staffs should no longer be satisfied with the books' and journals' management, they should undertake the work of solutions consulting. The reading room staffs usually carrying out the guide reading for the published books, at the same time, they should consider the specific circumstances of readers, and kindly take the initiative to introduce the readers the collection of books, shelving classification methods, procedures and the management rules of books' borrowing. The librarians can do the navigation work for the electronic literature and the network information, and to guide the readers to make fully good use of the various library literature resources, databases, and network information resources.

By using the superiority of university personnel, the librarians can improve the quality of guide reading. The guide reading work is not limited to library staffs, university libraries can take advantage of university personnel, invite different pro- fessional experts and scholars to involve in guiding work. Through the expert lectures and the professional consulting, it is a way to meet the different needs of the readers, in order to achieve the improvement of service quality. Library should often enrich the readers' activities and intensify propaganda to the readers. Through the network, display panels, literary and artistic works appreciation, famous celebrities talk about books, special lectures and other form activities of readers, to intensify their campaign guide and stimulate readers' interest, to cultivate the reader's information awareness and information query capabilities, to meet the different needs levels of the readers.

\section{Improve Service Level for Reading Room Staffs}

The staffs of library should improve the skills of network and computer application nowadays. The present world has become a sharing network of global information resource, mastering computer and network technology has become one of the basic requirements for the modern librarians. Reading room staffs should use the computer literate, knowledge and learning network, expertly use a variety of network methods and techniques. According to the needs of readers, check the latest and most cutting-edge academic information, and can focus on the collection of decentralized heterogeneous information, classification, screening, treatment, and timely available to readers.

A certain level of English is necessary for the library staffs. Today, there has been rapid development of science, resource sharing, information and mutual benefit today, the latest and most advanced scientific achievements, the most cutting-edge scientific and technological developments, academic developments are often appear in the foreign literature and periodicals. Librarians with a certain 
level of foreign language can achieve the collection, analysis and processing for the latest information.

Librarians should have the high and deep disciplinary expertise. With the development of modern science and technology, and mutual penetration of various disciplines of knowledge, then interdisciplinary science and fringe science continue to produce and appear. All these require librarians to master the expertise in library, librarians also should learn the relevant knowledge widely and continuously broaden their knowledge. Reading room staffs no longer just borrowing and returning books administrator, they are also the "navigator" of academic knowledge and information. The staffs should have a more profound professional knowledge in a scientific subject, and can professionally advise and answer the readers' questions, to carry out the highlevel professional literature information service work.

Reading room staffs should continue their education, they should have the planned, focused learning, changing the status of knowledge structure, and enhance the quality of their information, and adapt to the needs of today's rapid development of the information society.

\section{Summary}

In this paper, we study the reading service of university library in the network environment. We discuss the features of traditional reading service of library, and comparatively study the reading service of university library in nowadays. Especially, we consider Beijing Jiaotong University Library as the research objective, to study the modern management methods of the university library. This research shows that improving service level of university librarians is the key to the innovation of reading service of university library at the times of information, network and digital. The librarians with high-level service can achieve the valueadded of knowledge, form the latest information, provide readers with high-used valued, personalized and targeted services.

\section{Acknowledgements}

The authors were supported in part by National Natural Science Foundation of China Grant No. 71271026 and Grant No. 10971010. The authors would like to thank the support of the Library of Beijing Jiaotong University.

\section{References}

[1] S. Deng, J. Wang, "The Innovation of Service for University Library at the Times of Networks," 2010 International Conference on Management Science and Engineering, pp. 398400, 2010.

[2] S. Deng, J. Wang, "New Approach of University Library Journal Service in Chinese University," 2010 International Conference on Management Science and Engineering, pp. 394397, 2010.

[3] S. Deng, Study on the Periodical of University Library in Information Age, University Library Development and Innovation, Southwest Jiaotong University Press, Xian, 2004.

[4] S. Deng, Improving the Utilization of Scientific Journals in Reading Literature Department, University Library Development and Innovation, Southwest Jiaotong University Press, Xian, 2005.

[5] G. Han, New Thoughts of College Library Journals Services in Information Era, INFORMATION SCIENCE, vol. 2, 2002, pp. 136-137, 2002.

[6] J. He, A Thinking on Academic Library Information Service Under 
Network Environment, Library, vol. 4, pp. 81-82, 2004.

[7] J. Huang, To Innovate the idea of Service and Improve it in Libraries, Library, vol. 2, pp. 70-71, 2004.

[8] Z. Huang, Change the Concept to Run a Library in Order to Promote Library Services as Key and Push the Library Cause Development of Our Country, Library, vol. 1, pp. 7-12, 2008.

[9] P. Lin, The modern library and the basic meaning of service innovation, RESEARCHES IN LIBRARY SCIENCE, vol. 3, pp. 69-71, 2004.

[10] S. Liu, Periodicals Work of Academic Library in Network Environment, INFORMATION SCIENCE, vol. 4, pp. 370-372, 2002.

[11] X. Liu, On the Reader Service Work of Academic Library in the Network Age, Library, vol. 3, pp. 113-127, 2008.

[12] J. Yang, University Library Service innovation in the 21st Century, Library, vol. 1, pp. 58-60, 2004.

[13] B. Zhang, Reader Service of Library must Progress with Time, $\mathrm{Li}$ brary Tribune, vol. 4, pp. 157-158, 2004. 